\title{
Ecology and Conservation of Steppes and Semi-Natural Grasslands
}

\author{
Orsolya Valkón ${ }^{1, *}$, Michal Zmihorski², Idoia Biurrun ${ }^{3}$, Jacqueline Loos ${ }^{4}$, \\ Rocco Labadessa ${ }^{5}$ \& Stephen Venn ${ }^{6,7, *}$
}

Key words: abandonment, diversity, extensive agriculture, grasslands, homogenization, intensive agriculture, land-use change.

Ključne besede: opuščanje, diverziteta, ekstenzivno kmetijstvo, travišča, homogenizacija, intenzivno kmetijstvo, sprememba rabe tal.
Received: 20. 7. 2016

Revision received: 28. 7. 2016

Accepted: 28. 7. 2016

\begin{abstract}
Palaearctic grasslands encompass a diverse variety of habitats, many of high nature value and vulnerability. The main challenges are climate-change, land-use change, agricultural intensification and abandonment. Many measures are in place to address these challenges, through restoration and appropriate management, though more work is necessary. We present eight studies from China/Germany, Greece, Kazakhstan, Russia and Ukraine. The papers cover a wide range of grassland and steppe habitats and cover vegetation ecology, syntaxonomy and zoology. We also conducted a systematic search on steppe and grassland diversity. The greatest number of studies was from China, followed by Germany and England. We conclude that the amount of research being carried out on Eurasian grasslands is inadequate considering their high levels of biodiversity and vulnerability. We hope to encourage readers to address current major challenges, such as how to manage grasslands for the benefit of diverse taxa, to ensure that conservation initiatives concentrate on sites where there is good potential for success and for the generation of realistic and viable conservation strategies.
\end{abstract}

\begin{abstract}
Izvleček
Travišča zmerne palearktične regije predstavljajo raznolika življenjska okolja, med katerimi so številna naravovarstveno pomembna in ogrožena. Glavni izzivi, kot so klimatske spremembe, spremembe rabe tal, intenzifikacija kmetijstva in opuščanje rabe, so znani. Nanje skušamo odgovoriti z različnimi ukrepi, z obnovo in primernim gospodarjenjem $s$ travišči, vendar bo potrebno še veliko postoriti. V tej številki predstavljamo osem raziskav travišč na Kitajskem in v Nemčiji, Grčiji, Kazahstanu, Rusiji in Ukrajini. Članki pokrivajo širok izbor travišč in stepskih habitatov in predstavljajo vegetacijsko ekološke, sintaksonomske in zoološke vidike. Naredili smo tudi sistematično poizvedbo o člankih s tematiko raznolikosti step in travišč. Največje število raziskav je s Kitajske, sledita Nemčija in Anglija. Zaključimo lahko, da je število raziskav evrazijskih travišč nezadostno, če upoštevamo njihovo veliko raznolikost in ogroženost zaradi okoljskih sprememb. Upamo, da bo ta posebna številka vzpodbudila bralce, da se bodo usmerili v raziskave glavnih izzivov, na primer kako gospodariti na rastiščih v prid različnim vrstam, da se bodo naravovarstvene pobude osredotočile na rastišča z dobrim potencialom za uspeh ali za izdelavo nove generacije realnih in izvedljivih strategij ohranjanja.
\end{abstract}

1 MTA-DE Biodiversity and Ecosystem Services Research Group, Egyetem sqr. 1, 4032, Debrecen, Hungary. E-mail: valkoorsi@gmail.com

2 Institute of Nature Conservation, Polish Academy of Sciences, Mickiewicza 33, 31-120 Kraków, Poland. E-mail: michal.zmihorski@gmail.com

3 Department of Plant Biology and Ecology, University of the Basque Country UPV/EHU, Apdo. 644. 48080 Bilbao, Spain. E-mail: idoia.biurrun@ehu.es

4 Agroecology, Department of Crop Science, Georg-August University. Grisebachstrasse 6, 37077 Göttingen, Germany. E-mail: jloos@gwdg.de

5 Department of Agro-Environmental and Territorial Sciences, University of Bari, Via Orabona 4, 70125 Bari, Italy. E-mail: rocco.labadessa@gmail.com

6 Department of Environmental Sciences, University of Helsinki, P.O. Box 65 (Viikinkaari 2a), 00014, Finland. E-mail: stephen.venn@helsinki.fi

7 Department of Biosciences, University of Helsinki, P.O. Box 65 (Viikinkaari 1), 00014, Finland.

* Corresponding authors 


\section{Introduction}

Worldwide, grasslands play an important role for net primary production and comprise the most endangered terrestrial ecosystem (Török et al. 2016). Grasslands are increasingly declining due to local changes in management, often associated with intensified land-use or abandonment. In particular, steppes and temperate semi-natural grasslands are highly threatened by several global processes, such as climate change, the spread of invasive species, landuse change and urbanisation. Moreover, arid and semi-arid grasslands are particularly sensitive to climate change. Several studies have reported a decrease in grassland biodiversity and productivity, as well as alterations in the provision of ecosystem services in many regions, because of altered temperatures and decreased water availability (Lamarque et al. 2014, Dangal et al. 2016). Furthermore, human development has affected both the extent and diversity of grasslands through urbanisation and the spread of herbaceous and woody invasive species (Deák et al. 2016a). Thus, there is a need to develop conservation management strategies for grasslands that build upon diverse sources of local ecological knowledge of these sensitive systems. In this volume, we contribute to the basic understanding of different grassland systems across Eurasia, including countries from Central and Eastern Europe and Russia.

In many parts of the world, modern intensified agricultural practices generate new threats to grasslands through several mechanisms (Strijker 2005, Tälle et al. 2016). Grasslands, especially those with fertile soils (e.g. chernosems or castanosems) have been converted to croplands; this process is threatening steppes and several other types of semi-natural grasslands (Belonovskaya et al. 2016, this issue, Deák et al. 2016b, Dembicz et al. 2016). Other, less fertile grassland types are threatened by anthropogenic amelioration, such as the use of agrochemicals. Pesticides and fertilisers directly affect the grasslands, and they also have knock-on effects on associated adjacent natural and semi-natural habitats. The intensive use of fertilisers has resulted in a marked increase of the emission of reactive $\mathrm{N}$ (Zhu et al. 2015), which exacerbates the global effects of $\mathrm{N}$-deposition (Basto et al. 2015, Hüllbusch et al. 2016). These processes provide favourable conditions for nutrient-demanding and competitor species and decrease the establishment success of specialist species.

Furthermore, the overexploitation of grassland resources, such as overgrazing, is a typical phenomenon (Ambarl et al. 2016, Baranova et al. 2016, Wang \& Wesche 2016), leading to erosion, the disappearance of grassland specialist species and the encroachment of disturbance-tolerant and weedy species (Tölgyesi et al. 2015, Tóth et al. 2016).
Ramankutty et al. (2008) found that $50 \%$ of all temperate grasslands are utilised as pastures, and in many regions, overgrazing is common. Homogenization, resulting from mechanized and uniform mowing, is also a threat to grassland biodiversity, decreasing the availability and diversity of establishment microsites for grassland specialist species (Valkó et al. 2012). At the other extreme, socio-economic changes have led to the cessation of traditional grazing practices in many parts of Eurasia (Loos et al. 2015, Belonovskaya et al. 2016). The consequences of abandonment include litter accumulation, and encroachment of competitor grasses and woody vegetation, all leading to a decline in grassland biodiversity (Wellstein et al. 2014, Giarrizzo et al. 2015, Tälle et al. 2016). These mechanisms have their greatest impact on grassland specialist species, and can lead to their decline and extirpation, resulting in homogenization (Clavel et al. 2011).

\section{Motivation of the special issue}

This special issue complements the series of special features devoted to Palaearctic steppes and semi-natural grasslands (including Apostolova et al. 2014, Carboni et al. 2015, Dengler et al. 2013, 2014, Habel et al. 2013, Janišová et al. 2011, 2014, Ruprecht et al. 2015, Becker et al. 2016, Török et al. 2016), edited on behalf of the Eurasian Dry Grassland Group (EDGG, http://www. edgg.org). The present special feature was initiated by members of the EDGG attending the $12^{\text {th }}$ European Dry Grassland Meeting (EDGM) at Mainz, Germany, in May 2015 (Venn et al. 2016, this issue).

\section{Eurasian steppes and dry grasslands}

Palaearctic dry grasslands, especially basiphilous grasslands belonging to the class Festuco-Brometea, are important hotspots of small-scale vascular plant diversity (Wilson et al. 2012). In addition to vascular plants, dry grasslands of the class Koelerio-Corynephoretea can also harbour high diversity of bryophytes and lichens (Dengler et al. 2016). Although recent publications on grassland diversity have largely focused on semi-natural grasslands (Chytrý et al. 2015, Kuzemko et al. 2016), there is some evidence that also natural Palaearctic steppes, which are still very much understudied, could be extremely rich in small grain sizes (Polyakova et al. 2016).

In addition to plants, dry grasslands support a diverse and specialised animal fauna, including many rare and threatened invertebrates (McLean 1990, WallisDeVries et al. 2002). For example, dry calcareous grasslands and steppes are among the most important habitats for the 
conservation of butterflies in Europe (Van Swaay 2002). In some cases, rare grassland specialist species, such as the planthopper Ribautodelphax imitans, have been found to be highly abundant in isolated patches of suitable habitat (Dittrich \& Helden 2016). A number of studies have suggested that in grassland ecosystems there is a link between biodiversity and ecosystem function (Hector \& Bagchi 2007, Zavaleta et al. 2010) and that rare species are important for ecosystem function (Lyons et al. 2005, Soliveres et al. 2016). Changes in grassland quantity and management are also crucial for the conservation of many other arthropod taxa, including spiders, beetles and grasshoppers (Báldi \& Kisbenedek 1999, Bell et al. 2001, Woodcock et al. 2005, Labadessa et al. 2015). However, integrating the requirements of both flora and fauna is an important issue for the conservation of grasslands and one which requires research (WallisDeVries et al. 2002).

Maintaining the local biodiversity of grasslands may eventually support the conservation of the species pool of entire landscapes. Conservation management, however, needs to build upon an understanding of the effects of different spatial and temporal scales on biodiversity in grasslands (Pärtel et al. 1996, Poschlod et al. 1998). Grasslands are species-rich habitats, and complement other types of land-cover, with many species requiring different habitats at different stages in their life cycles (Venn et al. 2015). Therefore it is important to consider grasslands as integral elements of entire landscapes rather than isolated islands of biodiversity. The landscape is composed of different landuse types and structural elements which, in their particular arrangement, lead to different degrees of spatial heterogeneity. Local heterogeneity is the main driver of local plant species distributions, however particular plant groups may exhibit different local-regional relationships in their responses to environmental factors at different spatial scales (Loos et al. 2015). Moreover, landscape-scale inputs, such as atmospheric nitrogen deposition and climate change, also affect habitat composition. Eventually, local-scale effects culminate at the regional level, with consequences at the landscape scale. When addressing such issues through the interpretation of data from empirical studies, it is often necessary to consider also the temporal scale. When conditions change in a habitat, species often respond with a considerable time delay, rather than disappearing immediately the conditions become unsuitable. Such a delayed response

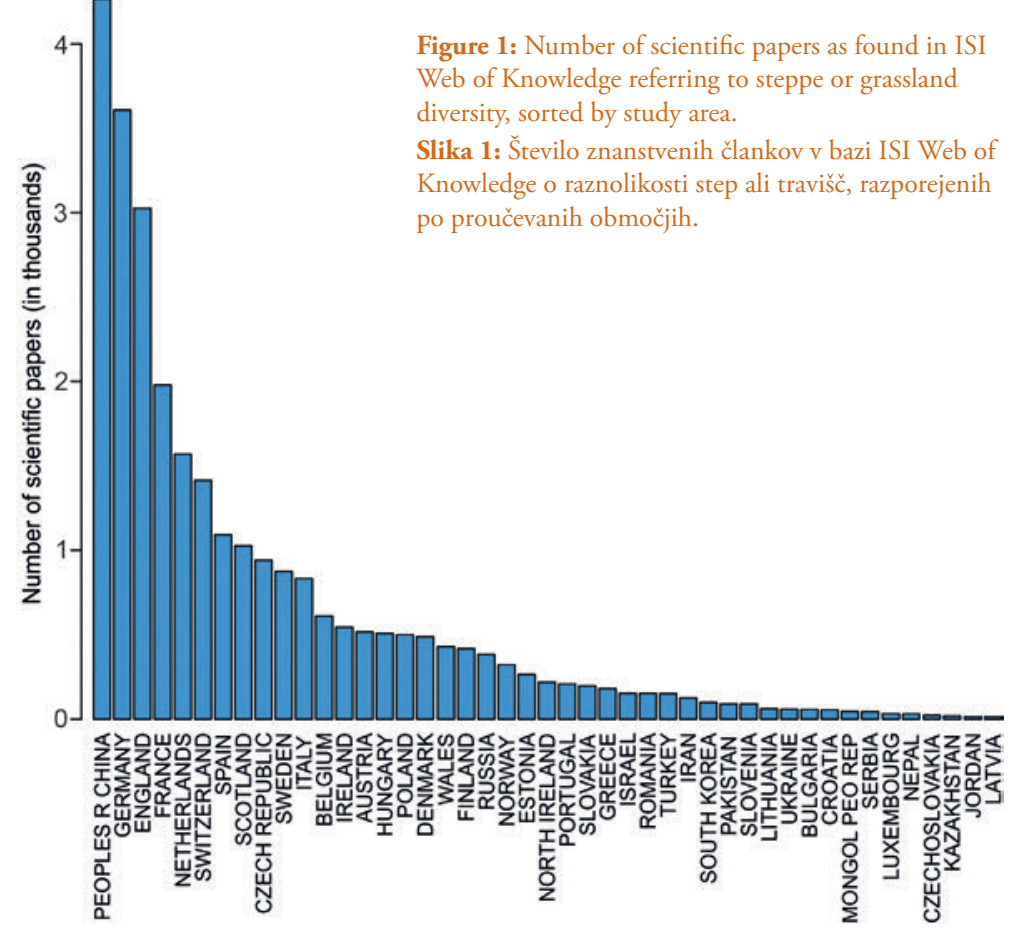

Figure 1: Number of scientific papers as found in ISI diversity, sorted by study area. Knowledge o raznolikosti step ali travišč, razporejenih

gives rise to an extinction gap (Kuussaari et al. 2009) or extinction debt (Hanski \& Ovaskainen 2002).

In many cases it is necessary to consider whether there is a risk of concentration of conservation efforts on too few and too small patches of grassland alone. In such cases it may be deceptive to proceed with restoration plans without considering whether the surrounding landscape fulfils the necessary requirements for providing source populations within a reasonable distance. If not, then it is unlikely that the desired effect of species conservation will be achieved over the long term, and it might be more feasible to concentrate the resources elsewhere. Also the question arises of who is responsible for managing these sites. Sometimes, grasslands constitute commons that have traditionally belonged to the entire community, with rules in place governing the frequency and intensity of their use. Also privately owned hay meadows and pastures have been incorporated into conservation schemes, but often the labour-intensive practices become less and less viable in cultural landscapes, mainly due to low profitability, alternative employment and changed lifestyle. Other factors include new laws and regulations presupposed under the European Agricultural Policy and/ or global markets (Loos et al. 2015).

Despite the conservation importance of temperate grassland habitats, the number of publications on Eurasian steppes and dry grasslands is remarkably low, particularly in eastern parts of the region. We conducted a systematic search in the ISI Web of Knowledge database (1) 
using the search terms 'grassland' or 'steppe' and 'diversity' (Figure 1). China showed the greatest number of publications, in excess of 4000 papers, followed by Germany and England. Russia, which encompasses much of the steppe region, was not strongly represented, with less than 500 publications, immediately after Wales and Finland. It is possible that this figure underestimates the amount of research being done on grasslands in Russia if much of the work is not published in ISI English language journals. At the thin end of the $\mathrm{x}$-axis, there is a long succession of countries with only few publications on grasslands, many of which contain considerable reserves of grassland habitats. We can only conclude from this survey that the amount of research being carried out on Eurasian grasslands is quite inadequate given their high levels of biodiversity and vulnerability to environmental change. Whilst the EDGG is supporting initiatives for surveying and documenting the vegetation of these habitats, there is clearly still a great need for further research of other less studied taxa, particularly insects and other arthropods.

\section{Contributions of the special issue}

This special issue consists of eight contributions, from China and Germany (Baranova et al. 2016), Greece (Tsiobani et al. 2016), Kazakhstan (Bragina 2016), Russia (Belonovskaya et al. 2016, Polchaninova et al. 2016), and Ukraine (Budzhak et al. 2016, Kolomiychuk \& Vynokurov 2016, Ronkin \& Savchenko 2016). These papers cover a wide range of semi-natural grassland and steppe habitats across Eurasia and several aspects of vegetation ecology (Baranova et al. 2016, Belonovskaya et al. 2016, Ronkin \& Savchenko 2016), syntaxonomy (Budzhak et al. 2016, Kolomiychuk \& Vynokurov 2016) and zoology (Bragina 2016, Polchaninova et al. 2016, Tsiobani et al. 2016).

\section{Studies on vegetation ecology}

Baranova et al. (2016, this issue) studied plant communities of the Qilian Shan Mountains in China, in relation to altitudinal and grazing gradients. This is an important contribution about current environmental issues of a poorly studied region. Overgrazing is a major environmental problem in this region, threatening forest and rangeland sustainability. The vegetation of slightly, moderately and heavily grazed plots was sampled, and quantitative and qualitative relevé data were collected for vegetation classification by hierarchical cluster analysis.
To analyse relationships between vegetation and environmental factors and grazing pressure, the authors used Detrended Correspondence Analysis (DCA). Altitude and exposure had the strongest impact on plant community distribution. Their results supported the crucial role of slope aspect by showing that exposure (northernness) had a greater impact on vegetation differentiation than altitude in the whole catchment area. Their data, collected over a period of nine years, revealed a trend of pasture deterioration, shifts in dominant species and the replacement of good fodder grasses and forbs by unpalatable and toxic plant species. The authors emphasized that in order to enhance grassland quality, sustainable pasture management strategies should be implemented.

Belonovskaya et al. (2016, this issue) investigated the impacts of land-use changes on species composition of grasslands in the intermontane basins of the CentralCaucasus (Figure 2). The paper addresses an important knowledge gap by studying the long-term effects of abandonment and underuse of mountain grasslands in a rarely studied region. The authors collected 40 phytosociological relevés and performed numerical vegetation classification using the TWINSPAN algorithm, and the JUICE program. Within the region, post-forest, meadow-steppe and also some stands of subalpine grasslands had been used as croplands for centuries and have been transformed into grazing lands about 60 years ago. During the last 20 years, the grasslands have been underused or abandoned. Belonovskaya et al. (2016, this issue) revealed that the current spatial distribution of grasslands is different from the classic scheme of natural climateinduced vegetation distribution. The most unexpected finding was the convergence of plant communities: species composition followed altitudinal change to some degree, but did not reflect the humidity differences of different slope aspects. The authors assume that the present convergence of vegetation composition is a result of the homogenising effect of human impact over a long period, and a relatively short grassland development.

Ronkin \& Savchenko (2016, this issue) summarize long-term changes of the flora and vegetation of dry grasslands of North-East Ukraine (Kharkiv Region). Botanical monitoring was started at two sites in the region, in 1991, just after grazing intensity had been substantially reduced in most places due to political and economical reasons. This provided an opportunity to investigate the ecological effects of changes in management practices on dry grasslands. Firstly, the authors documented in detail the flora and vegetation present, including several rare and red-listed species, in the study area, which is spatially diverse due to distinct variation in natural conditions in the region, such as slope, type of soil and moisture. 


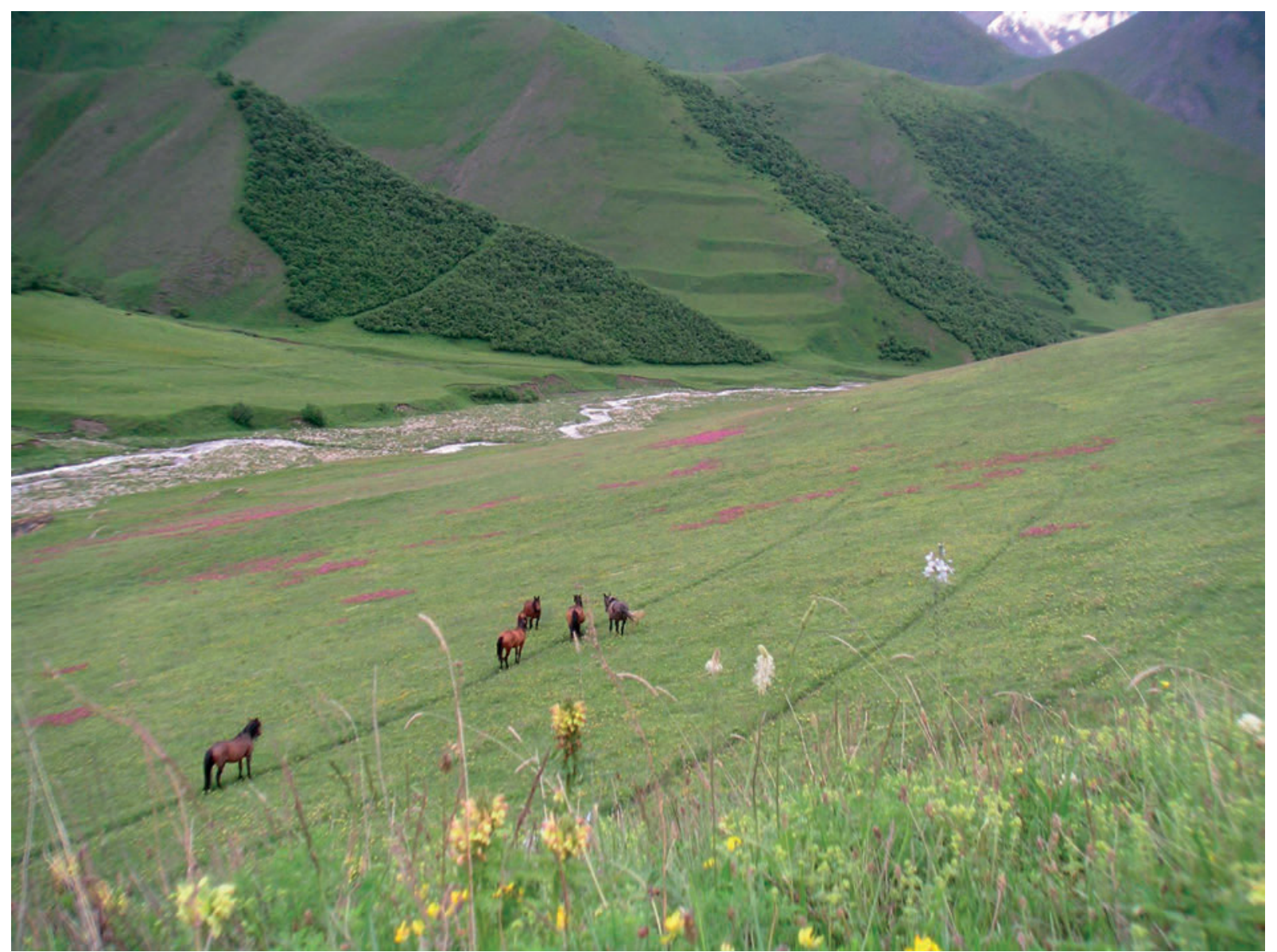

Figure 2: Typical landscape in the Central Caucasus, North Ossetia-Alania, Russia. Photo taken by Elena Belonovskaya.

Slika 2: Značilna krajina osrednjega Kavkaza, Severna Osetija-Alanija, Rusija. Foto: Elena Belonovskaya.

Secondly, they documented the main ecological effects of grazing on dry grassland communities. As the grazing intensity is spatially highly variable (usually more intensive close to villages), it was possible to analyze the full gradient of livestock pressure and distinguish separate successional stages of the grasslands. As a result of grazing abandonment, distinct species replacement was observed and the structure of the grasslands had clearly changed, with bush and tree encroachment evident while the herb layer was distinctly higher in such places. Sites that had been subjected to heavy grazing for a longer period of time, on the other hand, were usually affected by erosion and thus hosted specific plant communities and were usually less species-rich. Thirdly, the authors provide management recommendations. They conclude that mosaics of sites with variable grazing intensity (including sites without grazing) seem to be the most valuable from the perspective of conservation of grassland biodiversity. The authors suggest that this type of management may be achieved with the help of traditional extensive agricul- ture. With these insights concerning detailed documentation of dry grassland biodiversity and management, the recommendations of this paper contribute substantially to current knowledge on biodiversity conservation of dry grasslands in Ukraine.

\section{Syntaxonomical studies}

Global change alters plant communities, often towards a species composition dominated by highly competitive and generalist species. As an example, the purple moor grass Molinia caerulea expands in nutrient-poor environments, partly replacing highly adapted species such as those that are characteristic of heathlands and dry grasslands. Even though increased nitrogen deposition seems to favour the spread of Molinia, little is known about the reasons for the expansion of the Molinia caerulea species complex. Simultaneously, Molinia meadows are decreasing due to land abandonment, which eventually leads to succession of grasslands. Budzhak et al. (2016, this issue) study the 


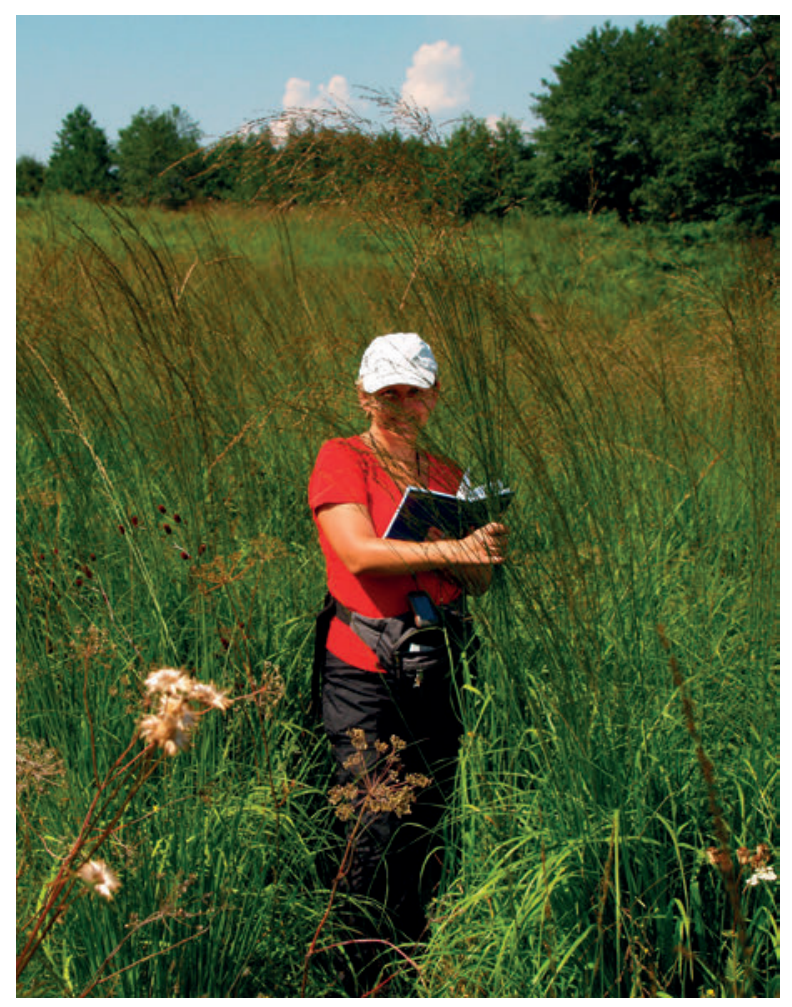

Figure 3: Molinion meadow in Ukraine. Photo taken by Vasyl V. Budzhak. Slika 3: Travnik iz zveze Molinion v Ukrajini. Foto: Vasyl V. Budzhak.

Molinia caerulea complex, which is represented by $M$. caerulea and $M$. arundinacea in south-western Ukraine. The authors separate vegetation associations in which Molinia occurred into nine different clusters, which differ between wet and dry species associations. They suggest that changes in Molinia occurrence were due to land-use changes. These land-use changes in southwestern Ukraine resemble those in other cultural landscapes: traditional land-use in this part of the landscape in the Carpathian Mountains, was regular haymaking. Haymaking served as a control for the spread of Molinia. In order to control the spread of Molinia also in the future, the application of a targeted management plan is needed, which should differ according to the vegetation association that is to be managed. In particular, $M$. caerulea associations should be managed differently from $M$. arundinacea communities. Such adapted management strategies that consider the seed maturation of the species are indeed important at a local scale to ensure either the maintenance of a particular plant community or to avoid the spread of very competitive species into adjacent, nutrient-poor biotopes. Eventually, management that helps maintain biodiversity in dry grasslands at a local scale, contributes to the conservation of biodiversity at regional and landscape scales. This paper emphasizes the importance of traditional land- use for the maintenance and control of vegetation associations that were formed through long-lasting human impacts on our ecosystems.

Kolomiychuk \& Vynokurov (2016, this issue) provide a comprehensive vegetation classification of natural steppes on the Sea of Azov coastal zone (Ukraine and Russia), a region where the vegetation remains quite unexplored. This is an important contribution to the knowledge or Palaearctic semi-natural grasslands and steppes included in the class Festuco-Brometea, performed by means of numerical analysis using the TWINSPAN algorithm. The authors have analyzed data from their study area together with data from other European regions, in order to contextualize these steppes into the frame of the accepted syntaxonomy of Festuco-Brometea. Four alliances and nine associations are recognized in the study area, all of which belong to the provisionally described new order Galatello villosae-Stipetalia lessingianae, which includes Pontic-Caspian true steppe vegetation (Vynokurov 2016). Ruderalized steppe communities, mainly overgrazed, are classified in the alliance Artemisio-Kochion prostratae, and saline steppe vegetation is included in the alliance Artemisio tauricae-Festucion valesiacae. Forb-bunchgrass steppes belong to the alliance Stipo lessingianae-Salvion nutantis, whilst bunchgrass steppes, characterized by high species diversity and many diagnostic species, are separated into the new alliance Tanaceto millefolii-Galatellion villosae. The authors provide a detailed description of the steppe communities of the study area, including distribution maps and lists of diagnostic, constant and dominant species, as well as a synoptic table with indication of the frequency and fidelity index of the species in each community. Photographs and detailed floristic tables with individual relevés of the four new associations are also available in this comprehensive vegetation survey. Kolomiychuk \& Vynokurov (2016) want to draw scientists' attention to the threats that these steppes are experiencing, such as the rising level of the Sea of Azov, and other factors associated with human activities that are increasing the abrasion-landslide coast area and thus significantly changing steppe communities, mostly by increasing the proportion of ruderal species and reducing their diversity. Thus, the present survey is particularly important, as it provides basic knowledge on the phytocenotic and floristic diversity of steppe communities in the frame of an ongoing degradation process.

\section{Zoological studies}

With reference to the clear need for initiatives aimed at documenting less studied taxa in less explored areas, a description of the soil-dwelling invertebrate diversity of the dry steppes of the Turgai Plateau, in Kazakhstan, has 
been reported by Bragina (2016, this issue). Indeed, despite the well-known role of the soil fauna in determining the functioning of terrestrial ecosystems (Lavelle et al. 2006), few studies have focused on these dry steppes of conservation concern, now acknowledged as part of a World Heritage site.

This study provides new information on the structure and composition of the poorly known invertebrate communities of Stipa lessingiana steppes in Kazakhstan. The author explored the occurrence and abundance of different invertebrate taxa within four soil layer depths, from 0 to $50 \mathrm{~cm}$. While reporting the overall high taxonomic diversity of the studied communities, the results underline the dominant role of insects. Indeed, with particular regard to the highly diverse order Coleoptera, insects represented over $80 \%$ of the total invertebrate abundance through all the soil layers. On the other hand, unlike other steppes, earthworms (Annellida Oligochaeta) were totally absent within the examined soil depths. Total invertebrate biomass and abundance were also found to be relatively low in comparison with other steppe communities, being rather similar to those of Mongolian and Kazakhstanian semi-deserts. These findings may be determined by the particularly dry and continental climate of the studied region, as well as by the consequently lower amounts of humus in the steppe soil. Moreover, among the sampled species, the occurrence of typical desert beetles seemed to be favoured by anthropogenic factors, i.e. recent extensive ploughing and overgrazing. Such changes in soil-dwelling community patterns may thus provide evidence of ongoing human-induced desertification of the steppe habitats.

The role of fire in conservation management is also controversial. Some plant species are pyrophytes and require exposure to fire for germination, and fire regimes are considered to be a valuable means of removing accumulated plant litter from grassland habitats (Klein 2013). However, in regions where fragmentation has reduced high conservation value habitats to a handful of remnants, then clearly there is a risk that large-scale fires could be calamitous. Also if such fires are anthropogenically caused or in regions where climate change has led to greatly increased fire risk, then clearly the fires may cause more harm than good for conservation purposes, and potential negative economical and health effects also support the implementation of measures for controlling fires. From the ecological perspective, there is clearly a need to investigate the effects of fire on vegetation, and also on other potentially vulnerable taxa in regions that are subject to wildfires. A study of spider and beetle assemblages of meadow steppe in Central European Russia during two seasons after a fire (Polchaninova et al. 2016, this issue) suggests that, in that region and habitat at least, these two taxa recover well. This also conforms with the result of an earlier study on the spider assemblages of a forb-Festuca-Stipa steppes in eastern Ukraine, which found that the spider assemblage recovered well after fire (Polchaninova 2015). However, as pointed out by Polchaninova (2016, this issue), these results cannot be considered sufficient to support the unconditional application of prescribed burning as a management regime, as epigaeic arthropods are generally highly mobile and re-colonize effectively, as long as there are suitable source populations nearby. Taxa that inhabit plant stems and leaf litter, for instance, are likely to be much more vulnerable to the effects of fire and are more difficult to investigate, as they are difficult to sample in an effective and standardized manner (Polchaninova 2016).

Tsiobani et al. (2016, this issue) studied the grazing behaviour of Greek Water Buffalos, an ancient traditional buffalo breed that can be found in Northern Greece. This study suggests that low-intensity farming systems using local breeds are important for proper management of biodiversity and related ecosystem services in grasslands (see also Dengler et al. 2014, Török et al. 2014, Sutcliffe et al. 2015). Most papers concerning low-intensity grazing systems studied cattle and/or sheep grazing, while information on other types of grazing animals, such as Mediterranean river buffaloes, are rather scarce (but see Napolitano et al. 2007). Tsiobani et al. (2016, this issue) determined the monthly variation of the grazing routes of water buffaloes, the time devoted by the animals to the several grazing-related activities and also their social, self-grooming and aggressive behaviour, by focal sampling of six individuals during 12 months. They found that feeding was the main grazing-related activity of water buffaloes, followed by moving, wallowing, standing, ruminating, drinking and resting. Greek water buffaloes adjusted their grazing behaviour to climatic conditions and the availability of forage resources. The authors emphasise that extensive grazing by Greek water buffaloes and grassland management can be combined with the protection of this endangered local breed.

\section{Conclusions}

We hope that the papers contained in this Special Issue will encourage readers to become involved in the conservation of grasslands and their declining diversity. We also hope to stimulate researchers to conduct research that addresses the major knowledge gaps and focus their research on addressing current major challenges, such as how we can manage sites for the benefit of as many vulnerable taxa as possible, how to allow for extinction debt and other temporal issues and how to ensure that conservation 
initiatives concentrate on sites where there is good potential for success and for the generation of realistic and viable conservation strategies. There is also a further need for studies on a wider range of taxa. We also hope to see as many of you as possible at future EDGG conferences and events to engage in debate and review current research on grassland conservation.

\section{Acknowledgements}

We are grateful to all authors for their contributions in this special issue and to all the referees for their considerable input of time and effort. We are especially grateful to Aiko Huckauf, Siobhan Loftus and Laura Sutcliffe for their professional linguistic editing and the courtesy of the Eurasian Dry Grassland Group and the International Association for Vegetation Science for their financial support. O.V. was funded by OTKA PD 111807 grant and the Bolyai János Research Fellowship of the HAS during manuscript preparation.

\section{References}

Ambarlı, D., Zeydanlı, U. S., Balkız, O., Aslan, S., Karaçetin, E., Sözen, M., Ilgaz, C., Ergen, A. G., Lise, ... \& Vural, M. 2016: An overview of biodiversity and conservation status of steppes of the Anatolian Biogeographical Region. Biodiversity and Conservation. DOI 10.1007/s10531-016-1172-0.

Apostolova, I., Dengler, J., Di Pietro, R., Gavilán, R. \& Tsiripidis, I. 2014: Dry grasslands of Southern Europe: Syntaxonomy, management and conservation. Hacquetia 13: 5-18.

Baranova, A., Schickhoff, U., Wang, S. \& Jin, M. 2016: Mountain pastures of Qilian Shan: plant communities, grazing impact and degradation status (Gansu province, NW China). Hacquetia 15: 21-36.

Báldi, A. \& Kisbenedek, T. 1999: Orthopterans in small steppe patches: an investigation for the best-fit model of the species-area curve and evidences for their non-random distribution in the patches. Acta Oecologica 20: 125-132.

Basto, S., Thompson, K., Phoenix, G., Sloan, V., Leake, J. \& Rees, M. 2015: Long-term nitrogen deposition depletes grassland seed banks. Nature Communications 6: 6185.

Becker, T., Csecserits, A., Deák, B., Janišová, M., Sutcliffe, L.M.E. \& Wagner, V. 2016. Different approaches in grassland analysis Editorial to the 11th EDGG Grassland Special Feature. Tuexenia 36: 287-291.

Bell, J. R., Wheater, C. P. \& Cullen, W. R. 2001: The implications of grassland and heathland management for the conservation of spider communities: a review. Journal of Zoology 255: 377-387.

Belonovskaya, E., Gracheva, R., Shorkunov, I. \& Vinogradova, V. 2016: Grasslands of intermontane basins of Central Caucasus: land use legacies and present-day state. Hacquetia 15: 37-48.
Bragina, T. M. 2016: Soil macrofauna (invertebrates) of Kazakhstanian Stipa lessingiana dry steppe. Hacquetia 15: 105-112.

Budzhak, V. V., Chorney, I. I., Tokariuk, A. I. \& Kuzemko, A. A. 2016: Numeric syntaxonomical analysis of the communities with participation of species from Molinia caerulea complex in the southwest of Ukraine. Hacquetia 15: 63-78.

Carboni, M., Dengler, J., Mantilla-Contreras, J., Venn, S. \& Török, P. 2015: Conservation value, management and restoration of Europe's semi-natural open landscapes. Hacquetia 14: 5-17.

Chytrý, M., Dražil, T., Hájek, M., Kalnóková, V., Preslerová, Z., Šibik, J., Ujházy, K., Axmanová, I., Bernátová, D., ... \& Vymazalová, M. 2015: The most species-rich plant communities in the Czech Republic and Slovakia (with new world records). Preslia 87: 217-278.

Clavel, J., Julliard, R. \& Devictor, V. 2011: Worldwide decline of specialist species: toward a global functional homogenization? Frontiers in Ecology and Environment 9: 222-228.

Dangal, S. R. S., Tian, H., Lu, C., Pan, S., Pederson, N. \& Hessl, A. 2016: Synergistic effects of climate change and grazing on net primary production of Mongolian grasslands. Ecosphere 7: e01274.

Deák, B., Hüse, B. \& Tóthmérész, B. 2016a: Grassland vegetation in urban habitats - Testing ecological theories. Tuexenia 36: 379-393.

Deák, B., Tóthmérész, B., Valkó, O., Sudnik-Wójcikowska, B., Moysiyenko, I. I., Bragina, T. M., Apostolova, I., Dembicz, I., Bykov, N. I. \& Török, P. 2016b: Cultural monuments and nature conservation: a review of the role of kurgans in the conservation and restoration of steppe vegetation. Biodiversity and Conservation; DOI: $10.1007 / s 10531-016-1081-2$

Dembicz, I., Moysiyenko, I. I., Shaposhnikova, A., Vynokurov, D., Kozub, Ł. \& Sudnik-Wójcikowska, B. 2016: Isolation and patch size drive specialist plant species density within steppe islands: a case study of kurgans in southern Ukraine. Biodiversity and Conservation, DOI: $10.1007 / s 10531-016-1077-y$.

Dengler, J., Janišová, M., Török, P. \& Wellstein, C. 2014: Biodiversity of Palaearctic grasslands: a synthesis. Agriculture, Ecosystems and Environment 182: 1-14.

Dengler, J., Bergmeier, E., Willner, W. \& Chytrý, M. 2013: Towards a consistent classification of European grasslands. Applied Vegetation Science 16: 518-520.

Dengler, J., Biurrun, I., Apostolova, I., Baumann, E., Becker, T., Becker, U., Berastegi, A., Boch, S., Dembicz, I., ... \& Weiser, F. 2016: Scale-dependant plant diversity in Palaearctic grasslands: a comparative overview. Bulletin of the Eurasian Dry Grassland Group 31: 6-18.

Dittrich, A. D. K. \& Helden, A. J. 2016: The community ecology of Ribautodelphax imitans (Ribaut, 1953) (Hemiptera: Delphacidae), a rare UK planthopper in a distinct grassland habitat. Entomologica Austriaca 23: 87-95.

Giarrizzo, E., Burrascano, S., Zavattero, L. \& Blasi, C. 2015: New methodological insights for the assessment of temporal changes in semi- natural dry grasslands plant species composition based on field data from the northern Apennines. Hacquetia 14: 19-32.

Habel, J. C., Dengler, J., Janišová, M., Török, P., Wellstein, C. \& Wiezik, M. 2013: European grassland ecosystems: Threatened hotspots of biodiversity. Biodiversity and Conservation 22: 2131-2138.

Hanski, I. \& Ovaskainen, O. 2002: Extinction debt at extinction threshold. Conservation Biology 16: 666-673. 
Hector, A. \& Bagchi, R. 2007 Biodiversity and Ecosystem Multifunctionality. Nature 448: 188-191.

Hüllbusch, E., Brandt, L. M., Ende, P. \& Dengler, J. 2016: Little vegetation change during two decades in a dry grassland complex in the Biosphere Reserve Schorfheide-Chorin (NE Germany). Tuexenia 36: 395-412.

Janišová, M., Boch, S., Ruprecht, E., Reitalu, T. \& Becker, T. 2014: Continental dry grasslands from range margin to range centre Editorial to the 9th Dry Grassland Special Feature. Tuexenia 34: 347-353.

Janišová, M., Bartha, S., Kiehl, K. \& Dengler, J. 2011: Advances in the conservation of dry grasslands - Introduction to contributions from the 7th European Dry Grassland Meeting. Plant Biosystems 145: 507-513.

Klein, S. 2013: Feuermanagement in Steppenrasen (Engl. Prescribed burning of dry grassland) p. 291-299 . - In: Baumbach, H. [Ed.]: Steppenlebensraume Europas - Gefahrdung, Erhaltungsmasnahmen und Schutz. pp. 291-299, Thuringer Ministerium fur Landwirtschaft, Forsten, Umwelt und Naturschutz, Erfur pp. 456.

Kolomiychuk, V. \& Vynokurov, D. 2016: Syntaxonomy of the Festuco-Brometea class vegetation of the Azov Sea coastal zone. Hacquetia 15: 79-104.

Kuussaari, M., Bommarco, R., Heikkinen, R. K., Helm, A., Krauss, J., Lindborg, R., Öckinger, E., Pärtel, M., Pino, J., ... \& SteffanDewenter, I. 2009. Extinction debt: a challenge for biodiversity conservation. Trends in Ecology \& Evolution 24: 564-571.

Kuzemko, A. A., Steinbauer, M. J., Becker, T., Didukh, Y. P., Dolnik, C., Jeschke, M., Naqinezhad, A., Ugurlu, E., Vassilev, K. \& Dengler, J. 2016: Patterns and drivers of phytodiversity of steppe grasslands of Central Podolia (Ukraine). Biodiversity and Conservation 25. DOI: $10.1007 / s 10531-016-1060-7$.

Labadessa, R., Forte, L. \& Mairota, P. 2015: Exploring life forms for linking orthopteran assemblage and grassland plant community. Hacquetia 14: 33-42.

Lamarque, P., Lavorel S., Mouchet M. \& Quétier, F. 2014: Plant traitbased models identify direct and indirect effects of climate change on bundles of grassland ecosystem services. Proceedings of the National Academy of Sciences 38: 13751-13756.

Lavelle, P., Decaens, T., Aubert, M., Barota, S., Blouin, M., Bureau, F., Margerie, P., Mora, P. \& Rossic, J.-P. 2006: Soil invertebrates and ecosystem services. European Journal of Soil Biology 42: 3-15.

Loos, J., Turtureanu, P. D., von Wehrden, H., Hanspach, J., Dorresteijn, I., Frink, J. P., Fischer, J. 2015: Plant diversity in a changing agricultural landscape mosaic in Southern Transylvania (Romania). Agriculture, Ecosystems and Environment 199: 350-357.

Lyons, K. G., Brigham, C., Bibit, H. T. \& Schwartz, M. W. 2005: Rare Species and Ecosystem Functioning Conservation Biology 19: 1019-1024.

McLean, I. F. G. 1990: The fauna of calcareous grasslands. In: Hillier, S. H., Walton, D. W. H. \& Wells, D. A. (eds) Calcareous grasslands - ecology and management. Bluntisham Books, Huntingdon, pp 41-46.

Napolitano, F., Grasso, F., Saltalamacchia, F., Martiniello, P., Bilancione, A., Pacelli, C. \& De Rosa G. 2007: Grazing behaviour of buffalo heifers. Italian Journal of Animal Science 6: 1256-1259.
Pärtel, M., Zobel, M., Zobel, K. \& van der Maarel, E. 1996: The species pool and its relation to species richness: evidence from Estonian plant communities. Oikos 75(1): 111-117.

Polchaninova, N. 2015: Recovery of spider communities after a spontaneous summer fire in the forb-bunchgrass steppe of eastern Ukraine. Hacquetia 14: 79-96.

Polchaninova, N. Tsurikov, M. \& Atemasov, A. 2016: Effect of summer fire on cursorial spider (Aranei) and beetle (Coleoptera) assemblages in meadow steppes of Central European Russia.

Hacquetia 15: 113-132.

Polyakova, M. A., Dembicz, I., Becker, T., Becker, U., Demina, O. N., Ermakov, N., Filibeck, G., Guarino, R., Janišová, ... \& Dengler, J. 2016: Scale- and taxon-dependent patterns of plant diversity in steppes of Khakassia, South Siberia (Russia). Biodiversity and Conservation. DOI: 10.1007/s10531-016-1093-y.

Ramankutty N., Evan A. T., Monfreda C. \& Foley J. A. 2008: Farming the planet: 1. Geographic distribution of global agricultural lands in the year 2000. Global Biogeochemical Cycles 22: GB1003. DOI: $10.1029 / 2007$ GB002952.

Ronkin, V. \& Savchenko, G. 2016: Flora and vegetation of dry grasslands of Northeastern Ukraine, and problems of diversity conservation. Hacquetia 15: 49-62.

Ruprecht, E., Janišová, M., Sutcliffe, L., Boch, S. \& Becker, T. 2015: Dry grasslands of Central-Eastern and South-Eastern Europe shaped by environmental heterogeneity and human land use - Editorial to the 10th Dry Grassland Special Feature. Tuexenia 35: 321-328.

Strijker, D. 2005: Marginal lands in Europe - Causes of decline. Basic and Applied Ecology 6: 99-106.

Soliveres, S., Manning, P., Prati, D., Gossner, M. M., Alt, F., Arndt, H., Baumgartner, V., Binkenstein, J., Birkhofer, K., ... \& Allan, E. 2016: Locally rare species influence grassland ecosystem multifunctionality. Philosophical Transactions of the Royal Society B 371: 20150269.

Sutcliffe, L. M. E., Batáry, P., Kormann, U., Báldi, A., Dicks, L. V., Herzon, I., Kleijn, D., Tryjanowski, P., Apostolova, I., ... \& Tscharntke, T. 2015: Harnessing the biodiversity value of Central and Eastern European farmland. Diversity \& Distributions 21: 722-730.

Tälle, M., Deák, B., Poschlod, P., Valkó, O., Westerberg, L. \& Milberg, P. 2016: Grazing vs. Mowing: A meta-analysis of biodiversity benefits for grassland management. Agriculture, Ecosystems and Environment 222: 200-212.

Tölgyesi, C., Bátori, Z., Erdős, L., Gallé, R. \& Körmöczi, L. 2015: Plant diversity patterns of a Hungarian steppe-wetland mosaic in relation to grazing regime and land use history. Tuexenia 35: 399-416.

Török, P., Wesche, K., Ambarl, D., Kamp, J. \& Dengler, J. 2016: Step(pe) up! Raising the profile of the Palaearctic natural grasslands. Biodiversity and Conservation (in press).

Török, P., Valkó, O., Deák, B., Kelemen, A. \& Tóthmérész B. 2014: Traditional cattle grazing in a mosaic alkali landscape: Effects on grassland biodiversity along a moisture gradient. PlosONE 9: (5) Paper e97095.

Tóth, E., Deák, B., Valkó, O., Kelemen, A., Miglécz, T., Tóthmérész, B. \& Török, P. 2016: Livestock type is more crucial than grazing intensity: Traditional cattle and sheep grazing in short-grass steppes. Land Degradation \& Development. DOI: 10.1002/ldr.2514. 
Tsiobani, E. T., Yiakoulaki, M. D., Hasanagas, N. D., Menexes, G. \& Papanikolaou, K. 2016: Water Buffaloes' grazing behaviour at the Lake Kerkini National Park, Northern Greece. Hacquetia 15: 133-142.

Valkó, O., Török, P., Matus, G. \& Tóthmérész, B. 2012: Is regular mowing the most appropriate and cost-effective management maintaining diversity and biomass of target forbs in mountain hay meadows? Flora 207 (4): 303-309.

Van Swaay, C. A. M. 2002: The importance of calcareous grasslands for butterflies in Europe. Biological Conservation 104: 315-318.

Venn, S., Schulman, H., Törrönen, S., Salla, A., Pajunen,T., Kerppola, S., Paukkunen, J., Nieminen, M., Vilisics, F. \& Karjalainen, S. 2015: Helsinki, p. 323-377 in J. Kelsey (ed.)

Vertebrates and Invertebrates of European Cities, Springer Verlag, New York, pp. 700.

Venn, S., Ambarlı, D., Biurrun, I., Dengler, J., Janišová, M., Kuzemko, A., Török, P. \& Vrahnakis, M. 2016: The Eurasian Dry Grassland Group (EDGG) in 2015. Hacquetia 15: 15-19.

Vynokurov, D. 2016: Classification of Pontic-Caspian true steppe vegetation: preliminary overview. In: Agrillo, E., Attorre, F., Spada, F. \& Casella, L. (eds.), 25th Meeting of European Vegetation Survey, 6-9 April 2016. Book of Abstracts. Lectures, Roma, p. 74.
Wang, Y. \& Wesche, K. 2016: Vegetation and soil responses to livestock grazing in Central Asian grasslands: a review of Chinese literature. Biodiversity and Conservation. DOI: 10.1007/s10531-015-1034-1.

WallisDeVries, M. F., Poschlod, P. \& Willems, J. H. 2002: Challenges for the conservation of calcareous grasslands in north-western Europe: integrating the requirements of flora and fauna. Biological Conservation 104: 265-273.

Wilson, J.B., Peet, R.K., Dengler, J. \& Pärtel, M. 2012: Plant species richness: the world records. Journal of Vegetation Science 23: 796-802.

Woodcock, B. A., Pywell, R., Roy, D. B., Rose, R. J. \& Bell, D. 2005: Grazing management of calcareous grasslands and its implications for the conservation of beetle communities. Biological Conservation 125: 192-202.

Zavaleta, E.S., Pasari, J., Hulvey, K. \& Tilman, G.D. 2010 Sustaining multiple ecosystem functions in grassland communities requires higher biodiversity. Proceedings of the National Academy of Sciences 107: 1443-1446.

Zhu, J., He, N., Wang, Q., Yuan, G., Wen, D., Yu, G. \& Jia, Y. 2015: The composition, spatial patterns, and influencing factors of atmospheric wet nitrogen deposition in Chinese terrestrial ecosystems. Science of the Total Environment 511: 777-785. 